\title{
Nitrogen Dynamics and Soil Nutrient Status as Influenced by Tillage and INM Practices under Soybean - Cotton Rotation in Vertisol
}

\author{
A.B. Age*, P. R. Kadu, S. D. Jadhao, N. M. Konde, D.V. Mali, \\ B. A. Sonune and P.A. Gite \\ Department of Soil Science and Agricultural Chemistry, \\ Dr. Panjabrao Deshmukh Krishi Vidyapeeth, Akola-444104 (M.S.), India \\ *Corresponding author
}

Ke y w o r d s
Conservation
tillage, $\mathrm{NO}_{3}-\mathrm{N}$,
$\mathrm{NH}_{4}-\mathrm{N}$,
Vermicompost,
Phosphocompost,
Glyricidia leaf
manuring

\section{A B S T R A C T}

The present investigation was conducted during kharif 2017-18 with a view to study the nitrogen dynamics and soil nutrient status as influenced by tillage and INM practices under soybean - cotton rotation in Vertisol at Akola. The experiment was carried out with main plot comprises two treatments i.e. conservation tillage and conventional tillage and eight sub plot treatments of IPNS consisting of control, 100 per cent RDF and use of chemical fertilizer along with organic source of nutrient in which 50 per cent $\mathrm{N}$ applied through organic sources (FYM, wheat straw, glyricidia leaf manuring (GLM), composted cotton straw, vermicompost and phosphocompost) and remaining $\mathrm{N}$ was applied through chemical fertilizers. The experiment was framed in randomised block design with three replications. The results of present experiment indicated that, significantly highest seed cotton yield was recorded with the application of phosphocompost in conjunction with chemical fertilizers $\left(13.71 \mathrm{q} \mathrm{ha}^{-1}\right)$. Among tillage practices, the seed cotton (12.95 $\left.\mathrm{q} \mathrm{ha}^{-1}\right)$ and cotton stalk (25.62 $\mathrm{q} \mathrm{ha}^{-1}$ ) yield was recorded with the adoption of conservation tillage as compared to conventional tillage. The improvement in organic carbon $\left(6.47 \mathrm{~g} \mathrm{~kg}^{-1}\right)$ and available $\mathrm{N}\left(253.8 \mathrm{~kg} \mathrm{ha}^{-1}\right)$ was noted with the conservation tillage in combination with 50 $\% \mathrm{~N}$ through FYM + remaining RD through chemical fertilizer. The overall improvement in available $\mathrm{P}, \mathrm{K}$ and $\mathrm{S}$ was noted with the application $50 \% \mathrm{~N}$ through $\mathrm{FYM}+$ remaining $\mathrm{RD}$ through chemical fertilizer. However, the various inorganic $\mathrm{N}$ fractions viz; $\mathrm{NH}_{4}-\mathrm{N}$ $\left(12.58 \mathrm{mg} \mathrm{kg}^{-1}\right), \mathrm{NO}_{3}-\mathrm{N}\left(16 \mathrm{mg} \mathrm{kg}^{-1}\right)$ and mineral-N $\left(28.58 \mathrm{mg} \mathrm{kg}^{-1}\right)$ were increased significantly with the application of $50 \% \mathrm{~N}$ through FYM + remaining RD through chemical fertilizer. Among tillage practices, conservation tillage was found promising for higher retention of $\mathrm{NH}_{4}-\mathrm{N}\left(12.83 \mathrm{mg} \mathrm{kg}^{-1}\right), \mathrm{NO}_{3}-\mathrm{N}\left(14.66 \mathrm{mg} \mathrm{kg}^{-1}\right)$ and mineral-N (27.49 $\left.\mathrm{mg} \mathrm{kg}^{-1}\right)$.

\section{Introduction}

Indian agriculture has entered in a new phase of research and development from the green revolution era of enhancing crop productivity to resolving the new challenges emerged out from green revolution. In order to resolve these problems and to meet out emerging needs, the demand of efficient use and conservation of resources is creating the 
pressure on the researchers. Issues of resource conservation and maintaining their sustainability is important in view of facing problems of resource degradation along with the fundamental principle of reducing costs of crop production and increasing profitability. Agricultural systems are relying on approaches like sustainable agriculture or conservation agriculture, are not only able to support high productivity, but also preserve biodiversity along with environmental safeguards.

Conservation agriculture has emerged as a new paradigm to achieve the goals of sustainable agricultural production. It involves the new and innovative ways of generating and promoting technologies that focus on resource conservation as a way to enhance productivity in a sustainable manner. Conservation agriculture aims at reversing the process of degradation inherent to the conventional agricultural practices like intensive cultivation and burning or removal of crop residues. Aggressive seed bed preparation with heavy machinery lead to declining soil fertility, biodiversity and erosion. The nutrient needs of the Indian agriculture are so large that no single plant nutrient source be it fertilizers, organic manures, green manures or biofertilizers is in position to meet the entire plant nutrient demand. Therefore, resource conservation becomes a top priority and restoration of precious soil resource by way of innovative means of management is the need of the day.

Cotton (Gossypium spp.) is one of the important commercial crops known as "White Gold of Black Soil" in Maharashtra in general and in Vidarbha in particular, is a leading fiber crop and second most important crop in the world (Rajendran et al., 2005). The productivity of cotton in Maharashtra is 333 kg lint per ha (Anonymous, 2016). The economy of agricultural community of
Vidarbha is mostly dependent on the cotton. The area under cotton in Vidarbha is 14.22 lakh ha with production of 23 lakh bales. The reasons for low productivity includes erratic distribution of rainfall, imbalanced fertilizer use, poor quality seed, low adoption of improved agro-techniques and decline in soil health (Anonymous, 2016).

Most of the soils of the cotton growing areas are low in organic carbon, nitrogen and available phosphorus (Rattan et al., 1999). Considering soil as a only and finite source of crop production, increase in production and productivity can be achieved only through enhanced vis-a-vis sustained soil fertility by replenishment of removed nutrients in crop production system.

Therefore, it is the time now to develop such a crop management system that may sustain the soil and crop productivity in terms of maintenance of physical, chemical and biological properties of soil. This can be achieved with modification in existing tillage practices, integrated plant nutrient management in order to enhance and sustain the overall soil quality.

The hypothesis of this study is relevant use of conservation tillage and integrated nutrient management in various cropping systems is an important way for build-up of soil organic matter and thereby augmenting the soil fertility and soil quality. It reduces time, labour and machine operation as well as conserving moisture and reducing soil erosion and nutrient loss there by sustaining the crop yields as well as soil health.

In this context, the present investigation was planned to study the nitrogen dynamics and soil nutrient status as influenced by tillage and INM Practices under soybean - cotton rotation in Vertisol. 


\section{Materials and Methods}

The field experiment was conducted on at Research Farm of Department of Soil Science and Agricultural Chemistry, Dr. PDKV, Akola on soybean - cotton rotation in Vertisol. The soil of experimental site was Vertisol belonging to fine, smectitic, hyperthermic, Typic Haplusterts. It was calcareous in nature and moderately alkaline in reaction. The fertility status of the soil indicates that the soil was moderate in organic carbon, available nitrogen and phosphorus and very high in available potassium. The experiment was carried out with main plot comprises two treatments i.e. conservation tillage (CNS) (one harrowing and two weeding) and conventional tillage (CNV) (one ploughing, one harrowing, two hoeing and two hand weeding) and eight sub plot treatments of integrated plant nutrient system consisting of control, 100 per cent RDF and use of chemical fertilizer along with organic source of nutrient in which 50 per cent $\mathrm{N}$ applied through organic sources (FYM, wheat straw, glyricidia leaf manuring (GLM), composted cotton straw, vermicompost and phosphocompost) and remaining $\mathrm{N}$ was applied through chemical fertilizers. The experiment was framed in randomized block design with three replications. The variety of cotton was AKH 9916 (non Bt). The general recommended dose of fertilizer for rainfed cotton was 60:30:30 N, $\mathrm{P}_{2} \mathrm{O}_{5}$ and $\mathrm{K}_{2} \mathrm{O} \mathrm{kg}$ ha ${ }^{1}$. The N, $\mathrm{P}$ and $\mathrm{K}$ were applied in the form of urea, single super phosphate and muriate of potash. Treatment wise basal doses (half nitrogen and full phosphorus and potassium) of fertilizers were calculated and applied at the time of sowing and remaining half dose of nitrogen was applied at flowering to soybean and cotton, thoroughly mixed in the soil. The crop residues were decomposed by PDKV decomposer. FYM, wheat straw, composted cotton stalk, vermicompost and phoshpocompost and glyricidia foliage lopping applied as a source of nutrient in soil. The different organics and crop residues were applied as per treatments based on nutrient content. The crop residues and glyricidia foliage lopping were applied in between two rows of cotton crop and thoroughly mixed in the soil.

The treatment wise initial surface soil samples $(0-20 \mathrm{~cm})$ before sowing from experimental site and after harvest of crop was collected. The air dried samples were carefully and gently ground with the wooden pestle to break soil lumps (clods) and passed through sieve of $0.5 \mathrm{~mm}$ for organic carbon and $2 \mathrm{~mm}$ sieve for other soil parameters. Briefly, organic carbon was determined by the modified Walkley and Black method was followed (Nelson and Sommers, 1982). Available nitrogen was determined by alkaline permanganate method using microprocessor based automatic distillation system (Subbiah and Asija, 1956). Available phosphorus was determined by Olsen's method using $0.5 \mathrm{M}$ sodium bi-carbonate as an extractant using UV based double beam spectrophotometer (Watanabe and Olsen, 1965). Available potassium was determined by neutral normal ammonium acetate method using flame photometer (Hanway and Heidal, 1952). Available sulphur was determined by Morgan's reagent as extractant (Turbidimetric method) using UV based double beam spectrophotometer (Chesnin and Yien, 1950). Nitrate nitrogen $\left(\mathrm{NO}_{3}-\mathrm{N}\right)$ was determined by Devardas alloy stem distillation method by (Bremner, 1965).

Ammonical nitrogen $\left(\mathrm{NH}_{3}-\mathrm{N}\right)$ was determined by $\mathrm{MgO}$ stem distillation method by (Bremner, 1965). Mineral nitrogen was determined by $\mathrm{MgO}$ and Devarda's alloy stem distillation method by (Bremner, 1965). The seed cotton and cotton yield was recorded. The data subjected to statistical analysis as per Gomez and Gomez (1984). 


\section{Result and Discussion}

\section{Seed cotton yield}

The data in respect of seed cotton yield as influenced by tillage was significant (Table 1). However, numerically higher seed cotton yield was obtained with conventional tillage (12.95 $\left.\mathrm{q} \mathrm{ha}^{-1}\right)$ as compared to conservation tillage (11.68 q ha $\left.{ }^{-1}\right)$. Similar findings were reported by Namdeo et al., (2003). They reported that the yields of cotton grown in Vertisols at the end of fourth year have not shown significant variation from the results obtained on some soils properties indicated that the effect of various intensities of tillage on soil properties and crop yield needs to be the further ascertained. Among various IPNS practices, the seed cotton yield was significantly influenced by various IPNS practices. The significantly highest seed cotton yield was observed in $100 \% \mathrm{P}$ through phoshpocompost + remaining $\mathrm{N}$ through chemical fertilizer (13.71 q ha ${ }^{-1}$ ) followed by $50 \% \mathrm{~N}$ through FYM + remaining RD through chemical fertilizer (13.38 q ha $\left.{ }^{-1}\right)$ which were on par with each others. It may inferred that increase in seed cotton yield may be due to more availability and efficient use of nutrients. The increase in seed cotton yield due to integrated use of FYM and chemical fertilizers attributed to efficient utilization of nutrient from soil. Modhvadia et al., 2016 found that, significantly higher seed cotton and stalk yield was recorded with incremental dose of $\mathrm{N}$.

Interaction effect of tillage and IPNS on seed cotton yield was found significant. Significantly highest seed cotton yield was recorded with application of $100 \% \mathrm{P}$ through phoshpocompost + remaining $\mathrm{N}$ through chemical fertilizer in conservation tillage $\left(14.22 \mathrm{q} \mathrm{ha}^{-1}\right)$ followed by application of $50 \%$ $\mathrm{N}$ through FYM + remaining RD through chemical fertilizer $\left(14.20 \mathrm{q} \mathrm{ha}^{-1}\right)$. The interaction of conservation tillage with
Phosphocompost and FYM was found most beneficial and recorded highest seed yield of cotton. This can be attributed to the combined effect of conservation tillage in improving soil properties along with FYM which reflected in higher cotton yield. The application of glyricidia green leaf manuring noted comparable yield with the treatment of FYM which signifies the importance of conservation tillage with organics.

\section{Stalk yield of cotton}

Significantly higher stalk cotton yield was obtained with conservation tillage ( $25.62 \mathrm{q}$ ha $\left.{ }^{1}\right)$ as compared to conventional tillage (22.72 $\mathrm{q} \mathrm{ha}^{-1}$ ) (Table 1). As tillage helps to maintain moisture content due minimum soil disturbances, ultimately helps to reduce losses of nutrients. Maximum number of branches and number of bolls per plant was noticed by Jadhao et al., 2004. Although the yields of cotton grown in Vertisols at the end of fourth year have not shown significant variation from the results obtained on some soils properties indicated that the effect of various intensities of tillage on soil properties and crop yield needs to be the further ascertained. The significantly highest seed cotton yield $\left(28.0 \mathrm{q} \mathrm{ha}^{-1}\right)$ was recorded in $100 \% \mathrm{P}$ through phoshpocompost + remaining $\mathrm{N}$ through chemical fertilizer followed by application of $50 \% \mathrm{~N}$ through FYM + remaining RD through chemical fertilizer $\left(26.78 \mathrm{q} \mathrm{ha}^{-1}\right)$. It may inferred that increase in seed cotton yield may be due to more availability and efficient use of nutrients. Mariam et al., 2018 reported that, balanced use of $\mathrm{N}, \mathrm{P}$ and $\mathrm{K}$ reported to have higher dry weight of plant and fruit weight per plant of Okra (Abelmoschus esculantus L.).

\section{Organic carbon}

The organic carbon $\left(6.04 \mathrm{~g} \mathrm{~kg}^{-1}\right)$ content was higher in conservation tillage as compared to conventional tillage $\left(5.83 \mathrm{~g}^{\mathrm{kg}^{-1}}\right) \quad$ as 
conservation tillage helps in reducing oxidation of SOC in soil by maintaining proper moisture content in soil. The significant increase organic carbon content under conservation tillage can be attributed to less disturbance of the soil which might have helped in preservation of more carbon in soil reducing oxidation of carbon. Novak et al., (2009) noticed conservation tillage increases the soil organic carbon as compared to disc tillage system.

Among various nutrient management practices, significantly higher organic carbon (6.31 $\mathrm{g} \mathrm{kg}^{-1}$ ) was observed with the application of $50 \% \mathrm{~N}$ through FYM + remaining $\mathrm{RD}$ through chemical fertilizer. However, the conjoint use of chemical fertilizers with FYM, glyricidia green manure and phoshpocompost were found beneficial for maintaining organic carbon content compared to the use of only chemical fertilizers.

The increase in organic carbon content under integrated use of chemical fertilizers and organic manure treatments might have been due to direct incorporation of organic matter, better root growth and more plant residues addition.

The treatments of organics also recorded higher organic carbon in comparison to $100 \%$ $\mathrm{RDF}$, which is due to the use of fertilizer and organics, which helped in higher contribution of biomass to soil in the form of greater root biomass through crop stubbles and residues. The subsequent decomposition of these materials might have resulted into enhanced organic carbon content of soil. Ravankar et $a l$. , (2005) reported that, the highest organic carbon was found in the plot receiving inorganic fertilizers in combination with organics under sorghum-wheat cropping sequence in Vertisols in the long-term fertilizer experiments.

\section{Soil nutrient status}

\section{Available N}

The available nitrogen was significantly higher in conservation tillage (240.4 kg ha ${ }^{-1}$ ) as compared to conventional tillage $(230.9 \mathrm{~kg}$ $\mathrm{ha}^{-1}$ ). The nitrogen in the soil was conserved under conservation tillage due to less disturbance of soil. Similarly, the highest nitrogen recorded under conservation tillage because of less mechanical disturbance of soil. Similar results were reported by Dick (1983) they observed that, greater amount of nitrogen under no-tilled surface $(0-30 \mathrm{~cm})$ soil compared to minimum and conventional tillage. Khiani and More (1984) observed through a long term experiment that available nitrogen was higher due to harrowing (85.4 $\mathrm{kg} \mathrm{ha}{ }^{-1}$ ) than ploughing (81.1 $\left.\mathrm{kg} \mathrm{ha}^{-1}\right)$ in Vertisol.

The available $\mathrm{N}$ status after harvest of cotton in (2017-18) was significantly influenced by various nutrient management practices. Highest soil available nitrogen $\left(248.0 \mathrm{~kg} \mathrm{ha}^{-1}\right)$ was recorded with $50 \% \mathrm{~N}$ through FYM + remaining $\mathrm{RD}$ through chemical fertilizers. Application of organics along with chemical fertilizers helps in increasing available nitrogen status of soil. The application of inorganic fertilizers along with organic and addition of previous soybean biomass helped in maintaining available nitrogen status of soil under soybean-cotton rotation.

It was observed that considerable improvement in available $\mathrm{N}$ status was observed in all the treatments which involve combined application of crop residues and inorganic fertilizer over initial status. This might be attributed to improved physical properties of the soil coupled with enhanced microbial population. Several earlier studies also showed an increase in available $\mathrm{N}$ with the application of FYM + inorganic fertilizers (Surekha and Rao, 2009). 


\section{Available P}

Significantly higher available phosphorus was observed in conservation tillage $(23.20 \mathrm{~kg}$ ha ${ }^{1}$ ) as compared to conventional tillage (21.11 $\left.\mathrm{kg} \mathrm{ha}{ }^{-1}\right)$. Conservation tillage involves minimum soil disturbance, leaving comparatively higher amount of crop residue which mostly accumulate at the surface of soil, ultimately enhanced organic matter content in soil and availability of nutrient like phosphorus. Similar observations were also recorded by Sonune et al., (2012) also observed higher available $\mathrm{P}$ in black cotton soils and minimum tillage compared to conventional tillage.

The highest available phosphorus $(25.78 \mathrm{~kg}$ $\mathrm{ha}^{-1}$ ) observed with the application of $100 \%$ $\mathrm{P}$ through phoshpocompost + remaining $\mathrm{P}$ through chemical fertilizer which was significantly superior over all the other treatments and lowest available phosphorus was observed in control (14.96 kg ha $\left.{ }^{-1}\right)$ and $100 \% \operatorname{RDF}\left(20.07 \mathrm{~kg} \mathrm{ha}^{-1}\right)$. The increase in available phosphorus due to legume cultivation can be ascribed to the development of phosphorus solubilising organisms in the root zone of legumes reported by Sharma et al., (1986).

\section{Available K}

Higher available potassium was observed in conservation tillage $(356.13 \mathrm{~kg} \mathrm{ha})$ as compared to conventional tillage $(351.30 \mathrm{~kg}$ $\left.\mathrm{ha}^{-1}\right)$. Similar observation recorded by Sonune et al., (2012) in Vertisol and reported that available potassium was higher due to harrowing than ploughing in black soil.

Maximum available potassium $(366.52 \mathrm{~kg} \mathrm{ha}$ ${ }^{1}$ ) was noted with the application of $50 \% \mathrm{~N}$ through FYM + remaining RD through chemical fertilizer followed by $(365.88 \mathrm{~kg}$ ha 1) $50 \% \mathrm{~N}$ through GLM + remaining $\mathrm{RD}$ through chemical fertilizer, (364.26 $\left.\mathrm{kg} \mathrm{ha}^{-1}\right)$ $50 \% \mathrm{~N}$ through vermicompost + remaining RD through chemical fertilizer and $(362.97 \mathrm{~kg}$ $\mathrm{ha}^{-1}$ ) $100 \% \mathrm{P}$ through phoshpocompost + remaining $\mathrm{N}$ through chemical fertilizer. The increase in available $\mathrm{K}$ might be due to the reduction in potassium fixation and release of $\mathrm{K}$ due to the interaction of organic matter with clay, besides the direct $\mathrm{K}$ addition in available $\mathrm{K}$ pool to the soil reported by Suresh et al., (1999) and Jadhao et al., (2018).

\section{Available S}

The higher available sulphur was observed in conservation tillage $\left(12.84 \mathrm{mg} \mathrm{kg} \mathrm{kg}^{-1}\right)$ as compared to conventional tillage $(11.30 \mathrm{mg}$ $\mathrm{kg}^{-1}$ ). The increased availability of sulphur might be due to enhance the decomposition process and mineralization of the organic manures in conservation tillage. Improvement in available sulphur status under crop residues and green manuring also due to its ameliorative effect on improvement of physical and chemical properties which helps to improve the availability of native sulphur in the soil. The results corroborates with the findings reported by Bharambe et al., (2002).

The highest available sulphur (12.96 mg kg-1) was recorded in treatment receiving $50 \% \mathrm{~N}$ through FYM + remaining RD through chemical fertilizer followed by application of $100 \% \mathrm{P}$ through phoshpocompost + remaining $\mathrm{N}$ through chemical fertilizer (12.81 $\mathrm{mg} \mathrm{kg}^{-1}$ ), with application of $50 \% \mathrm{~N}$ through GLM + remaining $\mathrm{N}$ through chemical fertilizer $\left(12.50 \mathrm{mg} \mathrm{kg}^{-1}\right)$ which was significantly superior over control. The lowest available sulphur (9.46 mg kg-1) was recorded in treatment control. Available sulphur in both the crops (cotton and soybean) has shown increase over initial values which may be due to addition of biomass from previous year soybean crop. Dikshit et al., (1995) also noticed increased the available sulphur 
content with fertilization under continuous cropping (16 cycles of soybean-wheat and maize-fodder) in Vertisol. The Interaction between tillage and IPNS on available sulphur was non significant.

\section{Nitrogen dynamics}

The significantly higher $\mathrm{NH}_{4}-\mathrm{N} \quad(12.83$ $\mathrm{mg} \mathrm{kg}^{-1}$ ) and $\mathrm{NO}_{3}-\mathrm{N}$ (14.66 $\mathrm{mg} \mathrm{kg}^{-1}$ ) was recorded in conservation tillage as compared to conventional tillage. The significantly higher total mineral-N was recorded in conservation tillage (27.49 $\mathrm{mg} \mathrm{kg-})$ as compared to conventional tillage $(19.47 \mathrm{mg}$ $\mathrm{kg}^{-1}$ ). The higher $\mathrm{NH}_{4}-\mathrm{N}$ in conservation tillage as compared to conventional tillage might be due to more retention of moisture which prevent oxidation of ammonium to nitrate. Similar results of tillage on the distribution of various nitrogen forms in soil were reported by Chandra et al., (2017).

Table.1 Effect of tillage and IPNS on seed cotton and stalk yield of cotton under soybean-cotton rotation

\begin{tabular}{|c|c|c|c|c|c|c|}
\hline \multirow[t]{3}{*}{ IPNS } & \multicolumn{6}{|c|}{ Cotton yield $\left(q\right.$ ha $\left.^{-1}\right)$} \\
\hline & \multicolumn{3}{|c|}{ Seed cotton } & \multicolumn{3}{|c|}{ Stalk } \\
\hline & CNS & CNV & Mean & CNS & CNV & Mean \\
\hline Control & 8.74 & 7.68 & 8.21 & 16.90 & 15.15 & 16.03 \\
\hline $100 \% \mathrm{RDF}$ & 13.99 & 12.02 & 13.01 & 24.68 & 23.12 & 23.90 \\
\hline $\begin{array}{l}50 \% \mathrm{~N} \text { through } \mathrm{FYM}+\text { remaining } \\
\text { RD through chemical fertilizer }\end{array}$ & 14.20 & 12.57 & 13.38 & 29.70 & 23.86 & 26.78 \\
\hline $\begin{array}{l}50 \% \mathrm{~N} \text { through WS+ remaining } \mathrm{RD} \\
\text { through chemical fertilizer }\end{array}$ & 13.12 & 10.03 & 11.57 & 23.63 & 23.36 & 23.49 \\
\hline $\begin{array}{l}50 \% \mathrm{~N} \text { through GLM + remaining } \\
\text { RD through chemical fertilizer }\end{array}$ & 13.48 & 13.17 & 13.32 & 27.34 & 25.10 & 26.17 \\
\hline $\begin{array}{l}50 \% \mathrm{~N} \text { through composted cotton } \\
\text { stalk+ remaining } \mathrm{RD} \text { through } \\
\text { chemical fertilizer }\end{array}$ & 12.15 & 12.06 & 12.10 & 25.94 & 21.59 & 23.76 \\
\hline $\begin{array}{l}50 \% \mathrm{~N} \text { through vermicompost+ } \\
\text { remaining } \mathrm{RD} \text { through chemical } \\
\text { fertilizer }\end{array}$ & 13.59 & 12.80 & 13.19 & 26.44 & 24.00 & 25.22 \\
\hline $\begin{array}{l}100 \% \mathrm{P} \text { through phoshpocompost }+ \\
\text { remaining } \mathrm{N} \text { through chemical } \\
\text { fertilizer }\end{array}$ & 14.22 & 13.19 & 13.71 & 30.88 & 25.12 & 28.00 \\
\hline Mean & 12.95 & 11.68 & - & 25.62 & 22.72 & - \\
\hline & Tillage & NM & Int. & Tillage & NM & Int. \\
\hline $\mathrm{SE}(\mathbf{m}) \pm$ & 0.12 & 0.24 & 0.35 & 0.41 & 0.83 & 1.17 \\
\hline CD (at 5\%) & 0.35 & 0.71 & 1.00 & 1.19 & 2.38 & 3.37 \\
\hline
\end{tabular}


Table.2 Effect of tillage and IPNS on organic carbon of soil after harvest of cotton under soybean-cotton rotation

\begin{tabular}{|c|c|c|c|}
\hline \multirow[b]{2}{*}{ IPNS } & \multicolumn{3}{|c|}{ Organic carbon $\left(\mathrm{g} \mathrm{kg}^{-1}\right)$} \\
\hline & CNS & CNV & Mean \\
\hline Control & 5.39 & 5.25 & 5.32 \\
\hline $100 \%$ RDF & 5.71 & 5.61 & 5.66 \\
\hline $\begin{array}{l}50 \% \mathrm{~N} \text { through FYM + remaining RD through chemical } \\
\text { fertilizer }\end{array}$ & 6.47 & 6.34 & 6.31 \\
\hline $50 \% \mathrm{~N}$ through WS+ remaining RD through chemical fertilizer & 6.05 & 5.87 & 5.96 \\
\hline $\begin{array}{l}50 \% \mathrm{~N} \text { through GLM + remaining RD through chemical } \\
\text { fertilizer }\end{array}$ & 6.34 & 6.08 & 6.21 \\
\hline $\begin{array}{l}50 \% \mathrm{~N} \text { through composted cotton stalk+ remaining RD } \\
\text { through chemical fertilizer }\end{array}$ & 6.00 & 5.60 & 5.80 \\
\hline $\begin{array}{l}50 \% \mathrm{~N} \text { through vermicompost+ remaining RD through } \\
\text { chemical fertilizer }\end{array}$ & 6.10 & 5.73 & 5.92 \\
\hline $\begin{array}{l}100 \% \text { P through phoshpocompost + remaining } N \text { through } \\
\text { chemical fertilizer }\end{array}$ & 6.19 & 5.98 & 6.09 \\
\hline Mean & 6.04 & 5.83 & \\
\hline & Tillage & NM & Int. \\
\hline $\mathrm{SE}(\mathrm{m}) \pm$ & 0.05 & 0.09 & 0.13 \\
\hline CD (at 5\%) & 0.14 & 0.27 & 0.38 \\
\hline
\end{tabular}

Table.3 Effect of tillage and IPNS on available N of soil after harvest of cotton under soybeancotton rotation

\begin{tabular}{|c|c|c|c|}
\hline \multirow[t]{2}{*}{ IPNS } & \multicolumn{3}{|c|}{ Avail N $\left(\mathrm{kg} \mathrm{ha}^{-1}\right)$} \\
\hline & CNS & CNV & Mean \\
\hline Control & 210.5 & 207.1 & 208.9 \\
\hline $100 \%$ RDF & 247.0 & 242.0 & 244.5 \\
\hline $50 \% \mathrm{~N}$ through FYM + remaining RD through chemical fertilizer & 253.8 & 243.2 & 248.0 \\
\hline $50 \% \mathrm{~N}$ through WS+ remaining RD through chemical fertilizer & 240.0 & 231.8 & 235.9 \\
\hline $50 \% \mathrm{~N}$ through GLM + remaining RD through chemical fertilizer & 245.0 & 242.2 & 243.2 \\
\hline $\begin{array}{l}50 \% \mathrm{~N} \text { through composted cotton stalk+ remaining RD through } \\
\text { chemical fertilizer }\end{array}$ & 243.2 & 219.0 & 231.6 \\
\hline $\begin{array}{l}50 \% \mathrm{~N} \text { through vermicompost+ remaining RD through chemical } \\
\text { fertilizer }\end{array}$ & 243.6 & 229.4 & 236.5 \\
\hline $\begin{array}{l}100 \% \text { P through phoshpocompost+ remaining } N \text { through chemical } \\
\text { fertilizer }\end{array}$ & 244.6 & 236.6 & 241.1 \\
\hline Mean & 240.4 & 230.9 & \\
\hline & Tillage & NM & Int. \\
\hline $\mathrm{SE}(\mathbf{m}) \pm$ & 1.10 & 2.21 & 3.12 \\
\hline CD (at 5\%) & 3.13 & 6.38 & 9.02 \\
\hline
\end{tabular}


Table.4 Effect of tillage and IPNS on available macronutrients in soil after harvest of cotton under soybean- cotton rotation

\begin{tabular}{|c|c|c|c|}
\hline Treatments & $\mathbf{P}$ & $\mathbf{K}$ & $\mathbf{S}$ \\
\hline (a)Tillage & & $h^{-1}$ ) & $\left(\mathrm{mg} \mathrm{kg}^{-1}\right)$ \\
\hline Set I-Conservation tillage & 23.20 & 356.13 & 12.84 \\
\hline Set II -Conventional tillage & 21.11 & 351.31 & 11.30 \\
\hline $\mathrm{SE}(\mathbf{m}) \pm$ & 0.32 & 1.04 & 0.21 \\
\hline CD at $5 \%$ & 0.93 & 3.01 & 0.61 \\
\hline (b) Integrated plant nutrient system & & & \\
\hline Control & 14.96 & 311.60 & 9.46 \\
\hline $100 \%$ RDF & 20.07 & 353.58 & 11.23 \\
\hline $\begin{array}{l}50 \% \mathrm{~N} \text { through } \mathrm{FYM}+\text { remaining } \mathrm{RD} \text { through chemical } \\
\text { fertilizer }\end{array}$ & 25.52 & 365.52 & 12.96 \\
\hline $50 \% \mathrm{~N}$ through WS+ remaining $\mathrm{RD}$ through chemical fertilizer & 22.44 & 349.94 & 12.15 \\
\hline $\begin{array}{l}50 \% \mathrm{~N} \text { through GLM + remaining RD through chemical } \\
\text { fertilizer }\end{array}$ & 21.95 & 365.88 & 12.50 \\
\hline $\begin{array}{l}50 \% \mathrm{~N} \text { through composted cotton stalk+ remaining } \mathrm{RD} \\
\text { through chemical fertilizer }\end{array}$ & 22.45 & 356.37 & 12.38 \\
\hline $\begin{array}{l}50 \% \mathrm{~N} \text { through vermicompost+ remaining } \mathrm{RD} \text { through } \\
\text { chemical fertilizer }\end{array}$ & 24.04 & 364.26 & 12.30 \\
\hline $\begin{array}{l}100 \% \mathrm{P} \text { through phoshpocompost+ remaining } \mathrm{N} \text { through } \\
\text { chemical fertilizer }\end{array}$ & 25.78 & 362.97 & 12.81 \\
\hline $\mathbf{S E}(\mathbf{m}) \pm$ & 0.64 & 2.08 & 0.42 \\
\hline CD at $5 \%$ & 1.86 & 6.02 & 1.23 \\
\hline (c) Interaction & NS & NS & NS \\
\hline
\end{tabular}


Table.5 Effect of tillage and IPNS on inorganic $\mathrm{N}$ forms in soil after harvest of cotton under soybean-cotton rotation

\begin{tabular}{|c|c|c|c|}
\hline \multirow{2}{*}{$\begin{array}{l}\text { Treatments } \\
\text { (a)Tillage }\end{array}$} & \multicolumn{3}{|c|}{ Inorganic $\mathrm{N}$ forms $\left(\mathrm{mg} \mathrm{kg}^{-1}\right)$} \\
\hline & $\mathrm{NH}_{3}-\mathrm{N}$ & $\mathrm{NO}_{3}-\mathrm{N}$ & Mineral N \\
\hline Set I-Conservation tillage & 12.83 & 14.66 & 27.49 \\
\hline Set II -Conventional tillage & 7.55 & 11.92 & 19.47 \\
\hline $\mathrm{SE}(\mathrm{m}) \pm$ & 0.18 & 0.11 & 0.23 \\
\hline CD at $5 \%$ & 0.51 & 0.32 & 0.67 \\
\hline \multicolumn{4}{|l|}{ (b) Integrated plant nutrient system } \\
\hline Control & 6.44 & 8.20 & 14.64 \\
\hline $100 \%$ RDF & 8.10 & 12.28 & 20.38 \\
\hline $\begin{array}{l}50 \% \mathrm{~N} \text { through FYM + remaining RD through } \\
\text { chemical fertilizer }\end{array}$ & 12.58 & 16.00 & 28.58 \\
\hline $\begin{array}{l}50 \% \mathrm{~N} \text { through WS+ remaining RD through chemical } \\
\text { fertilizer }\end{array}$ & 10.15 & 12.92 & 23.07 \\
\hline $\begin{array}{l}50 \% \mathrm{~N} \text { through GLM + remaining RD through chemical } \\
\text { fertilizer }\end{array}$ & 11.72 & 15.73 & 27.45 \\
\hline $\begin{array}{l}50 \% \mathrm{~N} \text { through composted cotton stalk+ remaining RD } \\
\text { through chemical fertilizer }\end{array}$ & 10.07 & 12.22 & 22.29 \\
\hline $\begin{array}{l}50 \% \mathrm{~N} \text { through vermicompost+ remaining RD through } \\
\text { chemical fertilizer }\end{array}$ & 11.50 & 14.69 & 26.19 \\
\hline $\begin{array}{l}100 \% \text { P through phoshpocompost+ remaining } \mathrm{N} \\
\text { through chemical fertilizer }\end{array}$ & 10.97 & 14.33 & 25.30 \\
\hline $\mathbf{S E}(\mathbf{m}) \pm$ & 0.35 & 0.22 & 0.46 \\
\hline CD at $5 \%$ & 1.02 & 0.63 & 1.34 \\
\hline (c) Interaction & NS & NS & NS \\
\hline
\end{tabular}

The maximum $\mathrm{NH}_{4}-\mathrm{N}$ was observed with the addition of $50 \% \mathrm{~N}$ through FYM + remaining $\mathrm{RD}$ through chemical fertilizer $(12.58 \mathrm{mg} \mathrm{kg}$ $\left.{ }^{1}\right)$ followed by with the application of $50 \% \mathrm{~N}$ through GLM + remaining RD through chemical fertilizer $\left(11.72 \mathrm{mg} \mathrm{kg}^{-1}\right)$. The higher $\mathrm{NO}_{3}-\mathrm{N}$ was observed with the addition of $50 \% \mathrm{~N}$ through $\mathrm{FYM}+$ remaining $\mathrm{RD}$ through chemical fertilizer $\left(16.00 \mathrm{mg} \mathrm{kg}{ }^{-1}\right)$ followed by with application of $50 \% \mathrm{~N}$ through GLM + remaining RD through chemical fertilizer (15.73 $\left.\mathrm{mg} \mathrm{kg} \mathrm{kg}^{-1}\right)$. The higher total mineral $\mathrm{N}$ was observed with the addition of $50 \% \mathrm{~N}$ through FYM + remaining RD through chemical fertilizer $(28.58 \mathrm{mg}$ $\mathrm{kg}^{-1}$ ) followed by with application of $50 \% \mathrm{~N}$ through GLM + remaining RD through chemical fertilizer $\left(27.45 \mathrm{mg} \mathrm{kg}^{-1}\right)$. This result conformity with the findings of Bhattacharyya et al., (2013).

In conclusion, the higher seed cotton and stalk 
yield of cotton, soil nutrient status and inorganic forms of $\mathrm{N}$ were recorded in the conservation tillage practices as compared to the conventional tillage practice. Among the various integrated nutrient management system, the significantly highest seed cotton yield and stalk yield of cotton and available nutrients were recorded with application of $100 \% \mathrm{~N}$ through phosphocompost + remaining $\mathrm{P}$ through chemical fertilizer. The inorganic $\mathrm{N}$ fractions viz; $\mathrm{NO}_{3}-\mathrm{N}, \mathrm{NH}_{4}-\mathrm{N}$ and mineral-N were improved with the application of $50 \% \mathrm{~N}$ through FYM + remaining RD through chemical fertilizer followed by $50 \%$ $\mathrm{N}$ through GLM + remaining $\mathrm{RD}$ through chemical fertilizer.

\section{References}

Anonymous, 2016. www.cci.co.in.

Bharambe, P.R., A.S. Tajuddin, S. R. Oza and D. K. Shelke, 2002. Effect of irrigation and crop residue management on crop and soil productivity under soybeansorghum cropping system. J. Indian Soc. Soil Sci., 50(3): 233-236.

Bhattacharyya P., Nayak A.K., Mohanty S., Tripathi R., Shahid M., Kumar A., Raja R., Panda B.B., Roy K.S., Neogi S., Dash P.K., Shukla A.K., Rao K.S. 2013. Greenhouse gas emission in relation to labile soil $\mathrm{C}, \mathrm{N}$ pools and functional microbial diversity as influenced by 39 years long-term fertilizer management in tropical rice. Soil and Tillage Research, 129: 93-105.

Bremner, J. M. 1965. Inorganic forms of nitrogen. In: Black, C.A. (ed.) Methods of soil analysis. Part 2, American Society of Agronomy, Madison, pp 1179-1237.

Chandra A., S. K. Guru and T. C. Thakur. 2017. Impact of different tillage practices on soil biochemical parameters, root and shoot growth and yield attributes of winter wheat. $J$.
Pharmacognosy and Phytochemistry, 6 (5): 1915-1922.

Chesnin, L. and C. H. Yien, 1950. Turbidimetric determination of available sulphur. Soil Sci. Soc. Am. Proc. 15: 149-151.

Dikshit, P. R., S. K. Gauttan, O.R. Turker and S. K. Khatik, 1995. Effect of long term fertilizer application under multiple cropping sequence. J. Indian Soc. Soil Sci. 43(4): 503-506.

Gomez, K. A. and A. A. Gomez, 1984. Statistical Procedures for Agricultural Research, John Wiley \& Sons, New York. pp 241-266.

Hanway, J.J. and H. Heidel, 1952. Soil Analysis Methods, as used in Iowa State. College Soil Testing Laboratory, Iowa, Agriculture, 57: 1-31.

Jadhao S. D., Dipali Arjun, D.V. Mali, Muneshwar Singh, V.K. Kharche, R.H. Wanjari, P. R. Kadu, B. A. Sonune and P. N. Magare, 2018. Effect of LongTerm Manuring and Fertilization on Depth Wise Distribution of Potassium Fractions under Sorghum-Wheat Cropping Sequence in Vertisol. $J$. Indian Soc. Soil Sci., 66 (2): 172-181.

Jadhao J. G., Jadhao S. D., Ghodpage R. M., Ingole, A.S., 2004. Effect of different chemical sprays on reddening and morphotogical characters in Cotton (Gossypium hiriutum L.) PKV Res. J., 28 (2): 225-2282004

Khiani, K. N and D. A. More, 1984. Long term effect of tillage operation and farm yard manure application on soil properties and crop yield in Vertisol. $J$. Indian Soc. Soil Sci., 32: 392-393.

Mariam, P. S. Anal, P.S. Minsi and Edwin Luikham, 2018. Influence of nitrogen, phosphorus and potassium on growth, yield and quality of Okra cv. Parbhani Kranti under sub tropical condition of Manipur, The Bioscan (Supplent on Agronomy), 13(1): 255-259. 
Modhvadia, J. M., R.M. Solanki, B. S. Gohil and R.B. Thanki, 2016. Influence of irrigation schedule and nitrogen on yield attributes, yield and $\mathrm{N}$ uptake in Bt. Cotton (Gossypium spp.), The Bioscan (Supplent on Agronomy), 11(2): 1219-1222.

Namdeo, S. L., B. B. Parmar and K. S. Bangar, 2003. Preparation of phosphorus enriched compost and its effect on yield and phosphorus uptake by soybean grown in vertisols. Indian J. agric. Sci. 73 (9): 490-493.

Nelson, D. W. and L. E. Sommer, 1982. Total carbon, organic carbon and organic matter. In : Methods of Soil Analysis Part-II. Page, A.L. (Ed.). Am. Soc. of Agron. Inc. Soil Sci. Soc. Am. Madison, Wisconsin, USA, pp 539-577.

Novak, J. M., J. R. Frederick, P. J. Bauer, and D. W. Watts, 2009. Rebuilding organic carbon content in coastal plain soils using conservation tillage systems. Soil. Sci. Soc. Am. J. 73: 622-629.

Rajendran, A. L. M. V. Venugopalan, C. S. Paharaj, 2005 Cotton research towards sufficiency to Indian industry. Indian J. Agril. Sci, 75(11): 699-708.

Ravankar, H. N., N. N. Gajbhiye and P. A. Sarap, 2005. Effect of organic manures and inorganic fertilizers on yield and availability of nutrients under sorghumwheat sequence. Indian J. Agric. Res., 39(2): 142-145.

Rattan, R. K., S. Neelan and S. P. Datta, 1999. Micronutrient depletion in Indian soils: extent, causes and remedies. Fertl. News. 44 (2): 35-50.

Sharma, C. P., B. R. Gupta and P. D. Bajpai, 1986. Residual effect of leguminous crops on some chemical and microbiological properties of soil. $J$. Indian Soc. Soil Sci. 34:206-208.

Subbiah, B.V and G. L. Asija, 1956. A rapid procedure for the determination of available nitrogen in soil. Curr. Sci. 25:259-260.

Sonune, B. A., V. V. Gabhane, S. S. Rewatkar and M.S. Sawangikar, 2012. Productivity of rainfed cotton and soil health as influenced by tillage and integrated nutrient management in Vertisol under semi-arid agroecosystem of Maharashtra. Indian J. Dryland Agric. Res. \& Dev. 27(1):1017.

Suresh, S., S. Subramanian, and T. Chitdeswari, 1999. Effect of long term fertilizers and manures in Vertisol. Under dry farming and soil properties. J. Indian Soc. Soil. Sci. 47 (2): 272-276.

Surekha, K. and K. V. Rao, 2009. Direct and residue effects of organic sources on rice productivity and soil quality of Vertisols. J. Indian Soc. Soil Sci., 37(1): 53-57.

Watanabe, F.S. and Olsen, S. R. 1965. Test of ascorbic acid method for determining phosphorus in water and sodium bicarbonate extracts of soils. Proc. Soil Sci. Soc. Am., 29: 677-678.

\section{How to cite this article:}

Age, A.B., P. R. Kadu, S. D. Jadhao, N. M. Konde, D.V. Mali, B. A. Sonune and Gite, P.A. 2020. Nitrogen Dynamics and Soil Nutrient Status as Influenced by Tillage and INM Practices under Soybean - Cotton Rotation in Vertisol. Int.J.Curr.Microbiol.App.Sci. 9(08): 509-520. doi: https://doi.org/10.20546/ijcmas.2020.908.058 